\title{
Peningkatan Kinerja Guru Teknik Komputer Jaringan Dalam Melaksanakan Pembelajaran Melalui Supervisi Klinis Di SMK Negeri Kota Blitar
}

\author{
${ }^{1}$ Imam Machfud, ${ }^{2}$ Abd.Charis Fauzan, ${ }^{3}$ Veradella Yuelisa Mafula \\ Dosen Ilmu Komputer Universitas Nahdlatul Ulama Blitar \\ Jl. Masjid No. 22 Kota Blitar, Jawa Timur, Indonesia
}
Email: 1imammachfud1962@gmail.com, 2abdcharis@unublitar.ac.id, 3veradella36@gmail.com

\section{Tersedia Online di \\ http://www.jurnal.unublitar.ac.id/ index.php/briliant}

\begin{tabular}{l}
\hline Sejarah Artikel \\
\hline Diterima pada Desember 2020 \\
Disetuji pada Mei 2021 \\
Dipublikasikan pada Mei 2021 \\
Hal. 410-415 \\
\hline
\end{tabular}

\begin{tabular}{l}
\hline Kata Kunci: \\
\hline Peningkatan kinerja guru; \\
pembelajaran; supervise klinis
\end{tabular}

\section{DOI:}

http://dx.doi.org/10.28926/brilian t.v3i4.606

\begin{abstract}
Abstrak: Penelitian ini bertujuan untuk mengetahui bagaimanakah supervisi klinis dapat meningkatktan kinerja guru Teknik Komputer Jaringan dalam melaksanakan pembelajaran di SMK Negeri Kota Blitar. Untuk mengetahui keefektifan hasil pelaksanaan supervisi klinis dalam meningkatkan kinerja guru dalam kegiatan pembelajaran perlu diadakan analisa data. Pada penelitian ini data dianalisa menggunakan teknik analisis deskriptif kualitatif, yaitu suatu metode penelitian yang bersifat menggambarkan kenyataan atau fakta kinerja guru sesuai data yang diperoleh dari instrumen yang telah disiapkan. Berdasarkan pengolahan data dan pembahasan yang dilakukan dapat disimpulkan bahwa kegiatan supervisi klinis dapat meningkatkan kinerja guru SMK Negeri Kota Blitar. Temuan ini dibuktikan adanya tingkat perkembangan penilaian kinerja guru mulai dari siklus pertama sampai siklus kedua ada peningkatan yang sangat signifikan. Pada siklus pertama rata-rata penilaian kinerja guru sebesar 75,94, siklus kedua naik menjadi 84,24. Implikasi temuan ini bahwa tindakan supervisi klinis yang
\end{abstract} dilakukan secara kemitraan yang baik dan bersifat terbuka dapat menjamin peningkatan kualitas kinerja guru semakin baik.

\section{PENDAHULUAN}

Dalam melaksanakan pembelajaan seharusnya sesuai dengan aturan standar proses yaitu pembelajaran dilakukan secara interaktif, inspiratif, menyenangkan, menantang, memotivasi peserta didik untuk berpartisipasi aktif, serta memberikan ruang yang cukup bagi prakarsa, kreativitas, dan kemandirian sesuai dengan bakat, minat, dan perkembangan fisik serta psikologis peserta didik.(Permendiknas 41,2007). Menurut Sardiman (2005:135) menegaskan bahwa guru yang profesional memiliki tiga tingkatan. Tingkat pertama adalah tingkatan capability personal, maksudnya guru diharapkan memiliki pengetahuan, kecakapan dan ketrampilan serta sikap yang lebih mantap dan memadai sehingga mampu mengelola proses belajar mengajar secara efektif. Tingkat kedua adalah guru sebagai inovator yakni guru diharapkan memiliki pengetahuan, kecakapan dan ketrampilan serta sikap yang tepat terhadap pembaharuan sekaligus merupakan penyebar pembaharuan yang efektif. Tingkat ketiga adalah guru sebagai developer yakni guru harus memiliki visi misi keguruan yang mantap dan luas prespektifnya dalam menjawab tantangan-tantangan yang dihadapi. Jadi guru yang profesional

410 BRILIANT: Jurnal Riset dan Konseptual Volume 6 Nomor 2, Mei 2021 
harus melaksanakan tugas, peran dan fungsi utama sebagai agen pembelajaran. Guru memiliki andil yang sangat besar terhadap keberhasilan pembelajaran di sekolah, sehingga guru harus memiliki sejumlah kompetensi yang tinggi dalam mengelola pembelajaran. Keberhasilan peserta didik dalam pembelajaran banyak dipengaruhi oleh kualitas kinerja guru. Guru berada pada baris terdepan sebagai ujung tombak untuk mencapai tujuan pendidikan nasional yang memiliki peran amat penting dalam mencerdaskan kehidupan bangsa sehingga guru merupakan kunci utama keberhasilan pendidikan yang berkualitas tanpa mengabaikan faktorfaktor pendukung yang lain. Di samping itu guru yang baik adalah guru yang memenuhi syarat-syarat kepribadian dan syarat-syatat teknis keguruan. (Hendyat Sutopo, 2005). Guru yang berkualitas akan mampu melaksanakan pembelajaran yang berkualitas dan menghasilkan hasil belajar yang berkualitas pula.

Berdasarkan hasil pengamatan dari peneliti menyimpulkan bahwa guru produktif Teknik Komputer Jaringan di SMK Negeri Kota Blitar dalam mengajar masih kurang interaktif, inspiratif, menantang, menyenangkan dan memotivasi, hal ini dapat dilihat dari hasil wawancara dengan peserta didik mengatakan bahwa pembelajaran TKJ kurang menarik. Setelah diidentifikasi masalah-masalah atau kendala-kendala yang dihadapi kemungkinannya adalah cara mengajar guru masih banyak ceramah, guru masih mendominasi kegiatan pembelajaran, kurang memberi kesempatan kepada peserta didik untuk berpikir kritis, mengajar kurang inovatif, kurang ada persiapan langsung mengajar, kurang menggunakan media/alat peraga. Pembelajaran TKJ seharusnya dapat meningkatkan kemampuan peserta didik untuk berpikir kritis, inovatif, mampu berinteraksi dengan lingkungan sumber belajar sehingga peserta didik mampu mengatasi masalahnya sendiri dalam kehidupan sehari-hari. Dari beberapa alternatif masalah tersebut yang paling penting dan amat mendesak yang harus segera diselesaikan adalah cara mengajar guru yang masih terlalu banyak ceramah. Proses pembelajaran harus dimulai dengan fase pengembangan rencana pelaksanaan pembelajaran, ketika kompetensi dan metodologi telah diidentifikasi, akan membantu guru dalam mengorganisasikan materi standar, serta mengantisipasi peserta didik dan masalah-masalah yang mungkin timbul dalam pembelajaran.(Mulyasa,2006).

Setelah diidentifikasi ada beberapa faktor penyebab munculnya masalah pembelajaran sehingga guru masih terlalu banyak ceramah: 1) guru senang pada kegiatan yang bersifat rutinitas; 2) kurang menggunakan media dengan baik; 3) strategi pembelajaran kurang variatif; 4) guru belum semua mengikuti kegiatan MGMP; 5) kurang pengalaman melaksanakan PTK; 6) pengetahuan guru tentang teknik pembelajaran kurang; 7) belum memahami berbagai strategi, metode dan teknik pembelajaran, 8) belum menggunakan media yang interaktif, 9) guru mengajar hanya untuk memenuhi jam pelajaran, 10) masih bergantung pada buku teks; 11) peserta didik dianggap memiliki kemampuan yang sama, 12) RPP hanya untuk formalitas keperluan administrasi saja; dan masih banyak faktor penyebab lainnya. Apabila penyebab ini tidak segera diselesaikan maka akan berakibat pada rendahnya mutu pembelajaran yang ujung-ujungnya dapat menurunkan hasil belajar peserta didik.

Adapun alternatif-alternatif penyelesaian masalah agar guru tidak selalu melakukan pembelajaran dengan cara ceramah maka perlu pendampingan, 
supervisi klinis atau dengan lesson study. Dari tiga alternatif tersebut yang terpilih sebagai solusi penyelesaian permasalahan pembelajaran adalah dengan cara supervisi klinis, dengan pertimbangan berbagai keterbatasan waktu, tenaga dan kemampuan peneliti. Agus Dharma (2004:374) menyebutkan beberapa cara untuk mengatasi semua hambatan itu dalam penilaian kinerja, supervisor harus benarbenar memperhatikan hal-hal berikut.

Supervisi klinis dapat dilakukan oleh guru senior yang berpengalaman, kepala sekolah atau pengawas sekolah. Dengan supervisi klinis ini dapat membantu, membimbing sekaligus menilai kinerja guru dalam rangka pengembangan diri dan perbaikan guru dalam pembelajaran.

Menurut Sergeovanni dan Starratt dalam Muyasa (2005:111) supervisi ditegaskan bahwa: "Supervision is a process designed to help teacher and supervisor learn more about their practice to better able to use their knowledge and skills to better serve parents and schools; and to make the school a more afective learning community"

Kutipan tersebut menunjukkan bahwa supervisi merupakan suatu proses yang dirancang secara khusus untuk membantu para guru dan supervisor dalam mempelajari tugas sehari-hari di sekolah; agar menggunakan pengetahuan dan kemampuannya untuk memberikan layanan yang lebih baik kepada orang tua peserta didik dan berupaya menjadikan sekolah sebagai masyarakat belajar yang lebih efektif.

Selanjutnya menurut Rutan Rusli dkk.(2002:96) menawarkan teori lain yaitu supervisi sumberdaya manusia (Human resources sepervision) Model ini dianggap sehat dan masuk akal dan lebih teliti dalam praktik supervisi dari pada supervisi berdasarkan pandangan ilmiah.

Jadi supervisi pembelajaran adalah upaya-upaya memberikan bantuan. Dengan menggunakan supervisi klinis ini diharapkan kinerja guru menjadi semakin baik dan kualitas pembelajaran meningkat serta kualitas output memiliki daya saing tinggi di era globalisasi. Ada beberapa alasan yang mendasari pentingnya supervisi ini. Pertama, supervisi pengajaran bertujuan untuk meningkatkan kualitas pembelajaran di sekolah. Kedua, supervisi pengajaran dapat memadukan perbaikan pengajaran secara relatif lebih sempurna secara bertahap. Ketiga, supervisi pengajaran memberikan dukungan langsung kepada guru dalam mengupayakan tercapainya tingkat kompetensi tertentu peserta didik. Keempat, supervisi pengajaran merupakan salah satu upaya meningkatkan kualitas dan kemampuan kinerja para guru.

Tujuan dari penelitian ini adalah: 1). untuk :meningkatkan kinerja guru Teknik Komputer Jaringan dalam melaksanakan pembelajaran melalui supervisi klinis di SMK Negeri Kota Blitar ; 2) meningkatkan kemampuan kepala sekolah/guru senior dalam melaksanakan supervisi klinis bagi guru Teknik Komputer Jaringan di SMK Negeri Kota Blitar.

\section{METODE}

Penelitian yang akan dilaksanakan ini adalah penelitian tindakan sekolah yang dirancang sebanyak dua siklus yang mana masing-masing siklus ada empat tahapan yaitu perencanaan, pelaksanaan, observasi dan refleksi. Berikut ini 
rancangan dari masing-masing siklus : (1) tahap perencanaan yaitu kegiatan perencanaan yang dilakukan oleh peneliti bersama-sama dengan kolabor adalah mengadakan pertemuan untuk membuat kesepakatan tentang jadwal pelaksanaan tindakan, membuat instrumen supervisi pra pembelajaraan, instrumen supervisi pelaksanaan kegiatan pembelajaran, instrumen supervisi post pembelajaran, instrumen pengamatan hubungan guru peserta didik, penilaian kinerja guru yang akan digunakan dalam pelaksanaan tindakan; (2) Tahap pelaksanaan tindakan yaitu kolabor mengadakan koordinasi sebelum melaksanakan supervisi pada guru untuk menyamakan persepsi dan langkah pelaksanakan supervisi ; (3) tahap observasi yaitu kegiatan yang dilakukan pada saat kegiatan pembelajaran dan supervisor melakukan pengamatan terhadap guru dan peserta didik selama proses pembelajaran berlangsung ; (4) tahap refleksi yaitu setelah jam pelajaran berakhir guru melakukan refleksi bersama dengan supervisor untuk melihat apakah kegiatan pembelajaran yang telah dilakukan berhasil atau belum. Bentuk refleksi berupa pertanyaan langsung tentang apa yang diperolehnya pada hari itu, diskusi hasil pembelajaran yang ditempuh serta membuat kesimpulan bersama dari pembelajaran yang baru saja dilaksanakan. Jika belum berhasil maka hasil dari refleksi pada siklus 1 digunakan untuk menyusun rencana perbaikan pada siklus 2 .

Subyek dalam penelitian ini adalah guru produktif TKJ SMK Negeri Kota Blitar. Pada penelitian ini peneliti masih mengutamakan subyek guru-guru yang mengajar mata pelajaran produktif Teknik Komputer Jaringan, sedangkan guru mata pelajaran yang lain akan dilanjutkan pada penelitian berikutnya dengan pertimbangan keterbatasan waktu tenaga dan biaya tidak mampu untuk melaksanakan secara menyeluruh.

Instrumen yang digunakan dalam penelitian ini adalah lembar observasi kegiatan pembelajaran, kuesioner/angket hubungan guru dan peserta didik, instrumen pra observasi, pos observasi dan instrumen penilaian kinerja guru. Lebih lanjut akan diuraikan berikut ini:

a) Instrumen pra observasi, instrumen ini digunakan untuk mengetahui kesulitan guru sebelum mengajar yang perlu mendapat bantuan dalam supervisi klinis, data yang diambil berupa data awal sebelum mengajar

b) Instrumen observasi kegiatan pembelajaran, instrumen ini digunakan observasi kegiatan pembelajaran untuk mengamati ketrampilan guru dalam mengelola atau melaksanakan pembelajaran, data yang diambil berupa data kemampuan guru dalam mengajar.

c) Lembar observasi aktivitas peserta didik dan guru, untuk mengamati hubungan antara guru dan peserta didik selama proses pembelajaran, data yang diambil berupa data aktivitas hubungan guru dan peserta didik selama pembelajaran.

d) Instrummen post observasi, instrumen ini digunakan untuk mengetahui hasil pembelajaran yang telah dilakukan guru

e) Instrumen penilaian kinerja guru, instrumen ini digunakan untuk menilai kinerja guru, data yang diambil adalah nilai kinerja guru

Instrumen penilaian kinerja guru yang digunakan dalam penelitian ini adalah kuesioner dengan skala likert, disebut skala likert karena pertama kali dikembangkan oleh Rensis Likert dengan memberi tanda cek (V) pada tempat yang telah disediakan pada kolom A, B, C, D, E dengan skore 5, 4, 3, 2, 1. 
Untuk mengetahui kefektifan hasil pelaksanaan supervisi klinis dalam meningkatkan kinerja guru dalam kegiatan pembelajaran perlu diadakan analisa data. Pada penelitian ini data dianalisa menggunakan teknik analisis deskriptif kualitatif, yaitu suatu metode penelitian yang bersifat menggambarkan kenyataan atau fakta kinerja guru sesuai data yang diperoleh dari instrumen yang telah disiapkan tersebut.

Perolehan data dari instrumen dianalisa dengan statistik sederhana, yang dapat dirumuskan sebagai berikut:

$$
X=\frac{P_{1}+P_{2}}{2}
$$

Dimana : $\mathrm{P}_{1}=$ pengamat $1 ; \mathrm{P}_{2}=$ pengamat 2 , dan menggunakan rumus:

$$
\text { Nilai }=\frac{\text { Skor Perolehan }}{\text { Skor Maksimal }} \times 100
$$

Berdasarkan hasil perhitungan dari skor instrumen ini dipergunakan untuk menilai kinerja guru dengan kriteria sbb.:

A = Istimewa, kinerja secara konsisten diatas standard (91-100)

$\mathrm{B}=$ Sangat memuaskan, standard kerja tinggi ( 81-90)

$\mathrm{C}=$ Memuaskan, kinerja efektif dan memenuhi standard (71-80)

D. $=$ Cukup, kinerja secara umum sudah memenuhi standard (61-70)

$\mathrm{E}=$ kurang, standard masih perlu dipenuhi $(<60)$

\section{HASIL DAN PEMBAHASAN}

Kinerja guru merupakan prestasi kerja yang dicapai guru dalam melaksanakan tugas untuk memperoleh hasil yang maksimal. Penilaian kinerja guru akan menjamin layanan pendidikan yang diberikan oleh guru adalah berkualitas dan profesional. Hasil penelitian memberikan nilai-nilai dimana tingkat perkembangan hasil supervisi pembelajaran menunjukkan bahwa pada siklus pertama rat-rata 76,54 dan pada siklus kedua rata-rata 86,24 berarti naik $9,14 \%$ hal ini dikarenakan adanya supervisi klinis yang dilakukan oleh supervisor pada pelaksanaan pembelajaran oleh guru-guru. Tingkat perkembangan hasil belajar sebagai dampak atas tindakan supervisi dari siklus pertama sampai siklus kedua menunjukkan kenaikan yang signifikan yaitu pada siklus pertama sebesar 84,00 dan pada siklus kedua 97,29 atau naik sebesar 13,66 \%. Tingkat perkembangan penilaian kinerja guru, siklus pertama rata-rata sebesar 75,94 atau masih pada kualifikasu Cukup, kemudian pada siklus kedua rata-rata 84,24 berarti memperoleh kualifikasi Baik berarti ada kenaikan sebesar 9,85\%, keberhasilan ini karena adanya saran-saran yang dilakukan pasca kegiatan supervisi klinis yang dilakukan oleh guru senior.

Dari data data tersebut dapat dipaparkan pada siklus pertama pada tahap perencanaan . tahap pelaksanaan tindakan dan observasi serta tahap refleksi bahwa hasil belajar peserta didik sebagai dampak dari kegiatan pembelajaran tersebut ratarata belum menunjukkan nilai standar yang diharapkan. Beberapa peserta didik yang mengikuti proses belajar bersama guru mengalami off task artinya peserta didik berada didalam kelas tetapi tidak dam kondisi belajar dan berdasarkan hasil 
pengamatan bahwa antusias peserta didik dalam mengikuti proses pembelajaran masih kurang. Kelemahan-kelemahan yang muncul pada siklus pertama menjadi bahan perbaikan dan penyempurnaan untuk melaksanakan pembelajaran pada siklus kedua dan menjadi fokus kedua dan menjadi fokus pelaksanaan supervisi kedua.

Pada siklus kedua tahap perencanaan, tahap pelaksanaan tindakan dan observasi serta tahap refleksi banyak mengalami peningkatan, interaksi peserta didik sudah baik, teknik bertanya sudah baik dan penggunaan media telah membuat peserta didik menjadi lebih aktif dan kreatif, membuat rangkuman sudah dilakukan bersama-sama, hasil belajar peserta didik mengalami peningkatan yang cukup signifikan, dimana nilai rata-rata hasil belajar peserta didik telah memenuhi standar ketuntasan yang ditetapkan. Faktor lain yang menyebabkan meningkatnya nilai hasil belajar adalah antusias dan kegairahan belajar yang mulai tumbuh dalam diri peserta didik. Guru bukan lagi sasu satunya sumber belajar, melainkan juga fasilitator dan mediator bagi peserta didik yang bisa membawa pengaruh positif pada proses berfikir peserta didik.

Hasil akhir kegiatan refleksi ini telah disepakati bahwa siklus ini sudah berakhir, untuk kegiatan berikutnya walaupun tanpa disupervisi akan dilakukan sebaik baiknya karena ternyata membawa dampak yang sangat baik bagi guru dalam melakukan pembelajaran maupun hasil belajar peserta didik menjadi meningkat.

\section{KESIMPULAN}

Berdasarkan hasil pembahasan dan analisis yang dilakukan sebanyak dua siklus, bahwa kegiatan supervisi klinis dapat meningkatkan kinerja guru dan membawa dampak positif terhadap aktivitas dan hasil belajar peserta didik, serta berpengaruh pada peningkatan kemampuan kepala sekolah/guru senior dalam melaksanakan supervisi untuk para guru. Temuan ini terbukti bahwa tingkat perkembangan penilaian kinerja guru mulai siklus pertama sampai siklus kedua ada peningkatan yang signifikan yaitu dari rata rata 76,54 naik menjadi rata rata 84,24 , atau naik sebesar $9,14 \%$.

\section{DAFTAR RUJUKAN}

Agus Dharma, 2004. Managemen Supervisi: Petunjuk Bagi Supervisor. Jakarta: PT Raja Grafindo Perkasa.

Muyasa, 2005. Menjadi Kepala Sekolah Profesional. Bandung: Remaja Rosdakarya

Permendiknas. 41/2007 standar Proses. Jakarta: Dikdasmen

Rutan, Rusli dkk. 2002. Supervisi Pendidikan Jasmani: Konsep dan Praktek. Jakarta: Dirjendikdasmen bekerjasama dengan Dirjen Olahraga

Sardiman, 2005. Interaksi dan Motivasi Belajar Mengajar. Jakarta: Raja Grafindo Persada

Sergeovanni, Thomas J dan Starratt, Robert J. 1998. Supervision: A Redifinition. New York: Mc Graw-Hill, Inc.

Soetopo, Hendyat. 2005. Pendidikan dan Pembelajaran, Teori, Permasalahan dan Praktik. Malang: Universitas Muhammadiyah Malang. 